\title{
Older migrants and loneliness: scanning the field and looking forward
}

\author{
Tineke Fokkema ${ }^{1,2}\left(\mathbb{D} \cdot\right.$ Ruxandra Oana Ciobanu $^{3,4}([)$
}

Accepted: 22 July 2021 / Published online: 4 August 2021

(c) The Author(s), under exclusive licence to Springer Nature B.V. 2021

\section{Introduction}

The scholarly literature on loneliness is vast and has been expanding in recent years. Because of increased concerns about the harmful health and societal implications of loneliness (Fokkema et al. 2012; Prohaska et al. 2020), there has also been more active policy attention. For example, the UK has a Minister of Loneliness, and in the Netherlands the Ministry of Health, Welfare and Sport launched the Action Programme Een tegen Eenzaamheid (United against loneliness) in 2018. During the coronavirus pandemic, interest in the issue of loneliness among young adults witnessed a revival (Groarke et al. 2020; Lee et al. 2020). Traditionally, however, loneliness has been mainly associated with older adults, even though it only peaks after the age of 80 (Dykstra 2009; Yang and Victor 2011).

Not all groups of older adults receive equal attention in loneliness research. In addition to LGBTQI (lesbian, gay, bisexual, transgender, queer, and intersex) older adults (for exceptions, see Fokkema and Kuyper 2009; Hsieh and Liu

Responsible Editor: Marja J. Aartsen.

Ruxandra Oana Ciobanu

oana.ciobanu@hetsl.ch

Tineke Fokkema

fokkema@nidi.nl

1 Netherlands Interdisciplinary Demographic Institute (NIDI)KNAW/University of Groningen, Lange Houtstraat 19, 2511 CV The Hague, The Netherlands

2 Department of Public Administration and Sociology, Erasmus School of Social and Behavioural Sciences, Erasmus University Rotterdam, Rotterdam, The Netherlands

3 Institute of Demography and Socioeconomics, Centre for the Interdisciplinary Study of Gerontology and Vulnerability, Swiss Centre of Expertise in Life Course Research, University of Geneva, 28 Bd du Pont d'Arve, 1205 Geneva, Switzerland

4 University of Applied Sciences and Arts Western Switzerland, Faculty of Social Work (HETSLIHES-SO), Chemin des Abeilles 14, 1010 Lausanne, Switzerland
2021), older migrants are such a neglected group. One reason is probably because they are a hard-to-reach population, especially for 'outsiders'. Yet it is remarkable and regrettable that so little attention is paid to older migrants, as they are generally considered particularly vulnerable and may be in double (Dowd and Bengtson 1978) or even triple jeopardy (Norman 1985). The few studies that included older migrants indeed show that, on average, they are at greater risk of loneliness than older adults without a migration background (Fokkema and Naderi 2013; Lin et al. 2016; Ten Kate et al. 2020; Uysal-Bozkir et al. 2017; Wu and Penning 2015).

The paucity of research on loneliness among older migrants has prompted us to put this topic in the spotlight by launching a call for papers and, as a result, devoting a Special section in the European Journal of Ageing to it. For the introduction to this Special section, we conducted a literature review of studies on loneliness among older migrants and identified several themes in relation to which the four papers in this Special section contribute to the body of knowledge: the limited recognition of diversity between and within the groups of older migrants (Ciobanu and Fokkema; 2020; Ehsan et al. 2020; Van Tilburg and Fokkema 2020); the standard practice of comparing older migrants with native-born older adults in the country of destination (Ehsan et al. 2020); the ambivalent role of social relationships and transnational belonging in protecting older migrants from loneliness (Albert 2021); and the lack of a life-course approach (Ciobanu and Fokkema 2020). We end this editorial with some reflections on the upcoming challenges and opportunities for the community of researchers working on older migrants and loneliness.

\section{Older migrants: who is studied, and who is being missed?}

First, we observe a narrow view on the population of older migrants. So far, the focus of previous studies on older migrants in the European context has been on the largest 
non-Western groups. These are the former guest workers, such as Turks and Moroccans, who arrived in Western Europe after the Second World War (El Fakiri and Bouwman-Notenboom 2015; Fokkema and Naderi 2013), and those from former colonies, such as Indians and Pakistanis in the UK (Victor et al. 2012) and Surinamese and Indonesians in the Netherlands (Kroon and Van Cooten 2006; Uysal-Bozkir et al. 2017). The common characteristic of these two groups is that they migrated at young ages, spent much of their working lives at the destination, and are now ageing in place.

The broader literature on older migrants shows that there are many more groups of migrants (Warnes et al. 2004) and this diversity will further increase in the future (Sampaio et al. 2018). Compared with the two groups mentioned above, these groups differ in many ways. The basis of this heterogeneity resides in the migration motives (e.g. joining their adult children who are migrants themselves, the search for better climate and quality of life, affordable care, work opportunities at an advanced age, escaping conflict and persecution), age at the time of migration and accordingly length of stay at the destination, and transnational mobility and opportunities (for a detailed description of distinct older migrant groups, see Ciobanu et al. 2017; King et al. 2017). These patterns of migration and ageing have most likely different bearings on loneliness in old age.

\section{Older migrants: how are they studied, and how should they be studied?}

So far, most qualitative and quantitative studies look at older migrants from one country of origin and when the data include older migrants of different countries of origin, researchers usually lump them together into one or a few groups. And yet there is great diversity among older migrants, even when only one specific subgroup is considered, such as former guest workers or migrants from former colonies. This diversity pertains to both pre- and postmigration circumstances. In the Netherlands, for instance, Moroccan older migrants were born in a less secular country and came more often from rural areas than their peers from Turkey (Dagevos et al. 2006; Fokkema et al. 2009; Smits et al. 2010), and post-colonial older migrants from Indonesia have on average better health than their Surinamese counterparts (Franse et al. 2018; Schellingerhout 2004).

A consequence of lumping older migrants of different origins together is that all of them are considered to be at high risk of loneliness and between-group variation in predictors of loneliness (and their importance) remains understudied (Ciobanu et al. 2017). The few studies that zoomed in on differences in the prevalence of loneliness by migrant origin show that the greater the cultural and linguistic distance between the country of origin and the country of destination, the greater the likelihood of above-average loneliness. In Great Britain, the rate of reported loneliness is high among older adults from Pakistan, Bangladesh, China, Africa, and the Caribbean, but not among those of Indian origin (Victor et al. 2012). In Canada, older migrants are on average lonelier than their native-born age peers, but not when they are of British or French origin (De Jong Gierveld et al. 2015) or when they identify themselves as such (Wu and Penning 2015).

Furthermore, with almost no exception, older migrants' loneliness is compared to that of native-born older adults in the country of destination. It is questionable whether this comparison is an accurate or even fair one. Leaving behind the familiar social and cultural environment and adapting to and feeling at home in the new environment can generate loss and cause stress (Berry et al. 1987). This is reinforced by experiences of social exclusion, disadvantage, and ethnic discrimination, with negative consequences that can last a lifetime. Hence, older migrants should ideally also be compared to their non-migrant peers in the country of origin, as this provides insight into the extent to which an explanation for the above-average level of loneliness among older migrants should be sought in migration/minority statusrelated effects or in cultural characteristics (e.g. individualistic versus collectivistic, Western versus non-Western, guilt versus shame culture) (Baretto et al. 2021).

\section{Lonely while not alone}

Many older migrants are socially embedded, often in their own families and communities (Fokkema and Das 2020; Palmberger 2017; Steinbach 2018). Social ties are at the core of loneliness. Hence at first glance, it seems paradoxical that older migrants would feel lonelier on average. Loneliness, however, is not only about the number of contacts one has, but also about their quality, and whether the existing contacts meet one's needs (Peplau and Perlman 1982).

The literature on care provision among older migrants highlights their strong reliance on family, particularly when they come from collectivistic countries. This manifests in strong family obligation norms, including regular family visits and children taking care of their frail parents (Carnein and Baykara-Krumme 2013; De Valk and Schans 2008). Although the second generation has often adopted these norms (Dykstra and Fokkema 2012; Merz et al. 2009), children are not always able to meet their parents' expectations due to their busy work and family life. As a result, older migrants can have more wishes and higher expectations than their offspring can fulfil, which may lead to intergenerational tensions and conflicts as well as feelings of disappointment and rejection-and hence loneliness (Liversage and Mizrahi 
Mirdal 2017; Nhass and Verloove 2020). Even when the children meet their parents' expectations, this does not guarantee harmonious relationships. While prior research has shown that overall relationship satisfaction reduces loneliness for both older migrants and non-migrants (De Jong Gierveld et al. 2015; Kim 1999; Ten Kate et al. 2020), little is known about different types of family conflicts and how they affect loneliness in old age.

\section{Transnational belonging: resource versus stressor}

Studies comparing the loneliness of older migrants with that of native-born peers in the country of destination are limited in their explanation of the role of general risk factors such as poor health and low socio-economic position. The benefit of studies exploring variation in loneliness within the group of older migrants is that they are able to examine the impact of migrant-specific factors such as language mastery (Cela and Fokkema 2017; Gautam et al. 2018), feelings of discrimination (Salma and Salami 2020), and sense of belonging to the mainstream society (Gautam et al. 2018; Klok et al. 2017). As these factors affect social interactions, it is not surprising that their observed effects on loneliness are in the expected direction: the less proficiently older migrants master the destination language, the more often they experience ethnic discrimination, and the less strongly they feel connected to the wider society, the lonelier they are. There is, however, one exception: the impact of transnational belonging-a feeling of belonging to the country of origin - which seems to be ambivalent.

Although there is no consensus on the accurate operationalization of the concept, scholars generally agree that transnational belonging has a behavioural and an emotional component (Boccagni 2012a, 2012b; Levitt and Glick Schiller 2004). The most common and documented examples of transnational behaviour are the back-and-forth trips between the place of destination and of origin, staying in contact with family and friends left behind, and sending remittances (Baldassar and Wilding 2020; Ciobanu and Ramos 2016; Fokkema et al. 2016; Klok et al. 2020). The emotional component refers to the imaginary attachment and orientation towards one's country of origin such as feelings of homesickness and nostalgia, longing for the presence of family and friends, return intentions and identifying with the country of origin (Baldassar 2008; Skrbiš 2008). In the literature, arguments can be found for both positive and negative effects of transnational belonging on loneliness (Horn and Fokkema 2020). For example, visiting the country of origin can make one feel surrounded by like-minded people, but upon return it can also heighten the emotions of a prolonged separation from relatives and friends. To the best of our knowledge,
Klok et al. (2017) are the only ones to have looked quantitatively at the impact of transnational belonging on loneliness among older migrants. Using data of older Moroccans and Turks in the Netherlands, none of the included indicators of transnational belonging showed an effect, except feelings of loss, which was positively related to loneliness. However, the scale's items were strongly related to the concept of loneliness (e.g. 'I miss the people I left behind in Morocco/ Turkey'), which might suggest that feelings of loss tell more about another type of loneliness specific to (older) migrants than about transnational belonging.

\section{Old-age loneliness from a life-course perspective}

In the attempt to explain the relatively high level and variations of loneliness among older migrants, the focus lies solely on potential predictors at the time of the interview. We observe, in fact, a lack of research investigating experiences that occurred throughout the life course, either prior or after migration, and which may have an impact on loneliness in later life. It is known from the literature on loneliness that older adults who did not follow the standard demographic and normative path are more likely to be lonely (Dykstra and De Jong Gierveld 2004; Zoutewelle-Terovan and Liefbroer 2018). Examples of deviation from this path are the non-occurrence of family life events (marriage, childbirth), negative turning points (divorce, unemployment), and offtime transitions (early or late parenthood, early widowhood). Knowledge is also lacking about the changes in loneliness feelings over the life course of older migrants, about whether having experienced loneliness is teaching people how to cope with it or, on the contrary, makes one weaker in future encounters with loneliness.

\section{How do the papers in the Special section contribute to the literature?}

This Special section put together four papers that contribute to the above-mentioned themes of research on older migrants and loneliness.

The paper by Albert (2021) examines the impact of risk and protective factors on loneliness of 131 middle-aged and older first-generation migrants from Portugal in Luxembourg. The central issue in her paper is the role of belonging. Specifically, she looks at the impact of two types of belonging on loneliness: cultural and intergenerational belonging. Attachment to Portugal—one of the indicators of cultural belonging-corresponds most closely to the concept of transnational belonging described above. Respondents were asked to rate their attachment to seven Portuguese symbols, 
including pictures of typical places, food, famous people, and the national flag. No significant correlation was found between attachment to Portugal and loneliness. Attachment to Luxembourg, on the other hand, correlates with loneliness: the more attached one is to Luxembourgian symbols, the less lonely he or she is. This negative correlation is overshadowed when a third indicator of cultural belonging is considered: conflicted cultural identity, which reflects the difficulties faced by individuals to reconcile both of their cultures and their confusions as to where they belong. In turn, the positive relationship between conflicted cultural identity and loneliness vanishes after controlling for indicators of intergenerational belonging, especially family conflict. Next to low socio-economic position and poor health, family conflict seems to be the main risk factor for loneliness: the stronger the respondent agrees that there are 'open conflicts, arguments, antagonism, and anger between family members' (Albert 2021, pp. 5-6), the lonelier he or she is.

Van Tilburg and Fokkema (2020) study 55-to-66-year-old Moroccan and Turkish migrants, which are the former international labour migrants who aged in place in the Netherlands. This group is one of the traditionally studied population. However, this paper adds to the existing scholarship by comparing the prevalence, and the risk and protective factors of loneliness between Moroccan and Turkish older migrants, and separately with those of their native-born Dutch peers. Controlled for age and gender, findings show the highest level of loneliness among Turkish older migrants, followed by their Moroccan counterparts. Also, after controlling for several risk and protective factors, Turkish older migrants remain the loneliest on average. Overall, there is a high degree of similarity in the importance of risk and protective factors for loneliness across the three groups. Exceptions are marriage (less protective for Moroccans), frequent contact with children/children-in-law (mostly for Turks), a higher educational level (protects Moroccans and Turks), and better physical functioning (less for Turks).

The paper by Ciobanu and Fokkema (2020) focuses on a group that has received little acknowledgement: former political refugees who fled from communist Romania to Switzerland when they were young and are now ageing in place. The starting point was an earlier finding that, contrary to common belief, this older migrant population experienced low levels of loneliness in old age (Ciobanu and Fokkema 2017). As a result, rather than focusing on general and migrant-specific risk factors for loneliness in later life, Ciobanu and Fokkema explore research participants' coping strategies as well as the underlying causes that shielded them from old-age loneliness, adopting a life-course approach and drawing on 21 in-depth interviews. Several interviewees experienced feelings of loneliness in their younger years, especially while living in the communist totalitarian regime in Romania and upon their arrival in Switzerland. However, because they migrated at a young age, they have had time to establish a sustainable social network and thus mitigate any social losses that may occur later in life. Moreover, having been through hard times in communist Romania-marked by interpersonal fear and distrust and estrangement from society - they built strength to withstand difficult times, learned to embrace solitude, and/or learned to relativise current hardships, if any. When feelings of loneliness are unavoidable (for example due to the loss of a spouse), they try to be active to distract themselves from loneliness or simply accept the circumstance.

Ehsan and colleagues (2020) examine loneliness of another group of older migrants that has received little to no attention-expats ageing in place. This is a rather privileged population from a socio-economic viewpoint, yet who rarely integrate and learn the destination language. In addition, although they did not compare expats to their peers in the country of origin (a gap in the literature described above), but to those in the destination country, their paper is nevertheless innovative in that it divides native-born into two groups: those who were born in the town in question (locals) and those who moved there (newcomers). The research setting was a town of about 10,000 residents in the French-speaking part of Switzerland, where a communitybased intervention-'Neighbourhoods in Solidarity'-was launched. Using mixed methods, the authors compare the level of loneliness before this intervention and the participation in the intervention among the three groups. Drawing on a survey among 235 respondents, Ehsan and her colleagues observed that the duration of residence in the town was significantly associated with loneliness before the intervention; the longer people have lived in the town, the less lonely they are. Drawing on qualitative data, they found that newcomers who moved within the same canton but had no ancestors in the town still are perceived and perceived themselves as migrants in spite of having lived there for extended periods of time. They were the most active in the community-based intervention aiming to build a sense of community, while expats barely participated in the intervention because they felt unwelcomed and discriminated against, and because of language barriers.

\section{Facing the future: opportunities and challenges}

From our literature review, we noted that the number of articles exploring loneliness among older migrants increased in recent years. Without pretending to be exhaustive, we also identified numerous gaps in the literature, almost all related to the limitations of existing datasets such as only one specific older migrant group, too-small cases per group of older migrants so that groups needed 
to be merged, only one country of destination or even one region in the destination country, no data on older adults in the country of origin, and no data on other periods of the life course. This severely limits our understanding of the phenomenon and does not allow us to speak about loneliness among older migrants, but at most about loneliness among older Portuguese in Luxembourg (Albert 2021), Moroccans and Turks in the Netherlands (Van Tilburg and Fokkema 2020), and Romanians or expats in Switzerland (Ciobanu and Fokkema 2020; Ehsan et al. 2020).

Although the four studies in this Special section contribute to gaps in our knowledge, more could be done to fully exploit the existing datasets. A study in progress by Conkova and colleagues, for example, demonstrates the unused potential of Dutch survey data on subjective well-being (including loneliness) among older migrants with some examples. Among other things, merging existing datasets allows comparing the well-being of several older migrant groups (or types of groups) or to analyse older migrants' well-being over time. This is why we strongly advocate for an open research data repository at the national and international level, where researchers can store and share their data. To further boost research on loneliness among older migrants, a new large-scale survey in several European countries would be a good investment, including more detailed migrant-specific questions (e.g. the meaning of some concepts for migrants themselves) and supplemented by a number of case studies.

At the same time, it would be important to set up practice-oriented research. Although a wide range of interventions have been developed to prevent or reduce loneliness among older persons (De Jong Gierveld and Fokkema 2015; Fakoya et al. 2020), only a few are designed specifically for older migrants (Salway et al. 2020). Academic interest and understanding on the effectiveness of loneliness interventions for older people —or the lack thereofis developing (Cattan et al. 2005; Dickens et al. 2011; Gardiner et al. 2018), whereas this is almost entirely absent for older migrants. Some qualitative studies do suggest that participation in social and cultural activities organised in migrant community centres is one of the most beneficial ways for older migrants to prevent or combat loneliness ( $\mathrm{Li}$ and Southcott 2012; Patzelt 2017; Tummala-Narra et al. 2013; Zhang and Zhan 2009), but quantitative evidence is lacking. Collaboration between researchers and practitioners is vital to explore, among other things, which already-proven loneliness interventions may also be useful for older migrants, what adaptations in existing interventions are needed to better meet older migrants' needs, what interventions older migrants themselves suggest, and what effect such interventions may have on loneliness.
Acknowledgements The work of Ruxandra Oana Ciobanu is funded by the Swiss National Science Foundation through the Professorship Grant 'Transnational Ageing among Older Migrants and Natives: A Strategy to Overcome Vulnerability', grant number PP00P1_179077/1.

\section{References}

Albert I (2021) Perceived loneliness and the role of cultural and intergenerational belonging: the case of Portuguese first-generation immigrants in Luxembourg. Eur J Ageing. https://doi.org/10.1007/ s10433-021-00617-7

Baldassar L, Wilding R (2020) Migration, aging, and digital kinning: the role of distant care support network in experiences of aging well. Gerontologist 60:313-321. https://doi.org/10.1093/geront/ gnz156

Baldassar L (2008) Missing kin and longing to be together: emotions and the construction of co-presence in transnational relationships. J Intercult Stud 29:247-266. https://doi.org/10.1080/0725686080 2169196

Barreto M, Victor C, Hammond C, Eccles A, Richins MT, Qualter P (2021) Loneliness around the world: age, gender, and cultural differences in loneliness. Personal Individ Diff 169:110066. https:// doi.org/10.1016/j.paid.2020.110066

Berry JW, Kim U, Minde T, Mok D (1987) Comparative studies of acculturative stress. Int Migrat Rev 21:491-511

Boccagni P (2012) Even a transnational social field must have its boundaries: methodological options, potential and dilemmas for researching transnationalism. In: Vargas-Silvia C (ed) Handbook of research methods in migration. Edward Elgar Publishing, Cheltenham, pp 117-132

Boccagni P (2012) Rethinking transnational studies: transnational ties and the transnationalism of everyday life. Eur J Soc Theo 15:117132. https://doi.org/10.1177/1368431011423600

Carnein M, Baykara-Krumme H (2013) Einstellungen zur familialen Solidarität im Alter: Eine vergleichende Analyse mit türkischen Migranten und Deutschen [Attitudes toward family solidarity in old age: a comparative analysis of Turkish migrants and Germans]. Zeitschrift für Familienforschung 25:29-52. https://nbnresolving.org/urn:nbn:de:0168-ssoar-386557

Cattan M, White M, Bond J, Learmouth A (2005) Preventing social isolation and loneliness among older people: a systematic review of health promotion interventions. Ageing Soc 25:41-67. https:// doi.org/10.1017/S0144686X4002594

Cela E, Fokkema T (2017) Being lonely later in life: a qualitative study among Albanians and Moroccans in Italy. Ageing Soc 37:11971226. https://doi.org/10.1017/S0144686X16000209

Ciobanu RO, Fokkema T (2017) The role of religion in protecting older Romanian migrants from loneliness. J Ethnic Migrat Stud 43:199-217. https://doi.org/10.1080/1369183X.2016.1238905

Ciobanu RO, Fokkema T (2020) What buffers older Romanians in Switzerland from loneliness? A life-course perspective. Eur J Ageing. https://doi.org/10.1007/s10433-020-00579-2

Ciobanu RO, Fokkema T, Nedelcu M (2017) Ageing as a migrant: vulnerabilities, agency and policy implications. J Ethnic Migrat Stud 43:164-181. https://doi.org/10.1080/1369183X.2016.1238903

Ciobanu RO, Ramos A-C (2016) Is there a way back? A state-of-the-art review of the literature on retirement return migration. In: Karl $\mathrm{U}$, Torres S (eds) Ageing in contexts of migration. Routledge, London/NewYork, pp 96-107

Conkova N, Fokkema T, Van Tilburg TG (in progress) Subjective well-being of older migrants in the Netherlands: a conceptual and methodological discussion

Dagevos J, Euwals R, Gijsberts M, Roodenburg H (2006) Turken in Nederland en Duitsland. De arbeidsmarktpositie vergeleken 
[Turks in the Netherlands and Germany. The labor market position compared]. Sociaal en Cultureel Planbureau

De Jong GJ, Van der Pas S, Keating N (2015) Loneliness of older immigrant groups in Canada: effects of ethnic-cultural background. J Cross-Cult Gerontol 30:251-268. https://doi.org/10. 1007/s10823-015-9265-x

De Jong Gierveld J (2015) Fokkema T (2015) Strategies to prevent loneliness. In: Shaked A, Rokach A (eds) Coping, prevention and clinical interventions. Routledge, New York

De Valk AG, Schans D (2008) 'They ought to do this for their parents': perceptions of filial obligations among immigrant and Dutch older people. Ageing Soc. https://doi.org/10.1017/S0144 686X07006307

Dickens AP, Richards SH, Greaves CJ, Campbell JL (2011) Interventions targeting social isolation in older people: a systematic review. BMC Public Health 11:647. https://doi.org/10.1186/ 1471-2458-11-747

Dowd JJ, Bengtson VL (1978) Aging in minority populations: an examination of the double jeopardy hypothesis. J Gerontol 33:427-436. https://doi.org/10.1093/geronj/33.3.427

Dykstra PA (2009) Older adult loneliness: myths and realities. Eur J Ageing 6:91-100. https://doi.org/10.1007/s10433-009-0110-3

Dykstra PA, De Jong Gierveld J (2004) Gender and marital-history differences in emotional and social loneliness among Dutch older adults. Canadian J Aging 23:141-155. https://doi.org/10.1353/cja. 2004.0018

Dykstra PA, Fokkema T (2012) Norms of filial obligation in the Netherlands. Popul Engl Ed 67:97-122

Ehsan A, Bolano D, Guillaume-Boeckle S, Spini D (2020) Reducing loneliness in older adults: looking at locals and migrants in a Swiss case study. Eur J Ageing. https://doi.org/10.1007/ s10433-020-00577-4

El Fakiri F, Bouwman-Notenboom J (2015) Gezondheid van oudere migranten in de vier grote steden [Health of older migrants in the four big cities]. GGD, Amsterdam

Fakoya OA, McCorry NK, Donnelly M (2020) Loneliness and social isolation interventions for older adults: a scoping review of reviews. BMC Public Health. https://doi.org/10.1186/ s12889-020-8251-6

Fokkema T, Cela E, Witter Y (2016) Pendular migration of older adults: misconceptions and nuances. In: Horn V, Schweppe C (eds) Transnational aging: current insights and future challenges. Routledge, New York, pp 141-161

Fokkema T, Das M (2020) Familienetwerken van niet-westerse oudere migranten [Family networks of non-Western older migrants]. In: Jaarrapport Integratie, CBS, pp 190-214

Fokkema T, De Jong GJ, Dykstra PA (2012) Cross-national differences in older adults loneliness. J Psychol 146:201-229. https://doi.org/ 10.1080/00223980.2011.631612

Fokkema T, Harmsen C, Nicolaas H (2009) Herkomst en vestiging van de eerste generatie Marokkanen in Nederland [Origin and settlement of the first generation of Moroccans in the Netherlands]. Bevolkingstrends: $51-56$

Fokkema T, Kuyper L (2009) The relation between social embeddedness and loneliness among older lesbian, gay, and bisexual adults in the Netherlands. Arch Sex Behav 38:264-275. https://doi.org/ 10.1007/s10508-007-9252-6

Fokkema T, Naderi R (2013) Differences in late-life loneliness: a comparison between Turkish and native-born older adults in Germany. Eur J Ageing 10:289-300. https://doi.org/10.1007/ s10433-013-0267-7

Franse CB, Van Grieken A, Qin L, Melis RJF, Rietjens JAC, Raat $\mathrm{H}$ (2018) Ethnic differences in frailty: a cross-sectional study of pooled data from community-dwelling older persons in the Netherlands. BMJ Open 8:e022241. https://doi.org/10.1136/bmjop en-2018-022241
Gardiner C, Geldenhuys G, Gott M (2018) Interventions to reduce social isolation and loneliness among older people: an integrative review. Health Soc Care Commun 26:147-157. https://doi.org/10. 1111/hsc. 12367

Gautam R, Mawn BE, Beehler S (2018) Bhutanese older adult refugees recently resettled in the United States: a better life with little sorrows. J Transcult Nurs 29:165-171. https://doi.org/10.1177/ 1043659617696975

Groarke JM, Berry E, Graham-Wisener L, McKenna-Plumley PE, McGlinchey E, Armour C (2020) Loneliness in the UK during the COVID-19 pandemic: cross-sectional results from the COVID-19 Psychological Wellbeing Study. PLoS ONE 15:e0239698. https:// doi.org/10.1371/journal.pone.0239698

Horn V, Fokkema T (2020) Transnational ties: resource or stressor on Peruvian migrants' well-being? Population. Space Place 26:e2356. https://doi.org/10.1002/psp.2356

Hsieh N, Liu H (2021) Social relationships and loneliness in late adulthood: disparities by sexual orientation. J Marriage Fam 83:57-74. https://doi.org/10.1111/jomf.12681

Kim O (1999) Predictors of loneliness in elderly Korean immigrant women in the United States of America. J Adv Nurs 29:10821088. https://doi.org/10.1046/j-1365-2648.1999.00993.x

King R, Lulle A, Sampaio D, Vullnetari J (2017) Unpacking the ageing-migration nexus and challenging the vulnerability trope. $\mathrm{J}$ Ethnic Migrat Stud 43:182-198. https://doi.org/10.1080/13691 83X.2016.1238904

Klok J, Van Tilburg TG, Fokkema T, Suanet B (2020) Comparing generations of migrants' transnational behaviour: the role of the transnational convoy and integration. Comp Migrat Stud 8:1-21. https://doi.org/10.1186/s40878-020-00206-0

Klok J, Van Tilburg TG, Suanet BA, Fokkema T, Huisman M (2017) National and transnational belonging among Turkish and Moroccan older migrants in the Netherlands: protective mechanisms against loneliness? Eur J Ageing 14:341-351. https://doi.org/10. 1007/s10433-017-0420-9

Kroon P, Van Cooten E (2006) Woningbehoefte Delftse allochtone ouderen - eindrapport [Housing needs of older migrants in Delft - final report]. Amsterdam: Regioplan

Lee CM, Cadigan JM, Rhew IC (2020) Increases in loneliness among young adults during the COVID-19 pandemic and association with increases in mental health problems. J Adolesc Health 67:714-717. https://doi.org/10.1016/j.jadohealth.2020.08.009

Levitt P, Glick Schiller N (2004) Conceptualizing simultaneity: a transnational social field perspective on society. Int Migrat Rev 38:1002-1039

Li MS, Southcott J (2012) A place for singing: active music engagement by older Chinese Australians. Int J Commun Music 5:59-78. https://doi.org/10.1386/IJCM.5.1.59_1

Lin X, Bryant C, Boldero J, Dow B (2016) Psychological well-being of older Chinese immigrants living in Australia: a comparison with older Caucasians. Int Psychogeriatr 28:1671-1679. https://doi.org/ $10.1017 / \mathrm{S} 1041610216001010$

Liversage A, Mizrahi Mirdal G (2017) Growing old in exile-a longitudinal study of migrant women from Turkey. J Ethnic Migrat Stud 43:287-302. https://doi.org/10.1080/1369183X.2016.1238910

Merz EM, Özeke-Kocabas E, Oort FJ, Schuengel C (2009) Intergenerational family solidarity: value differences between immigrant groups and generations. J Family Psychol 23:29-1300. https://doi. org/10.1037/a0015819

Nhass H, Verloove J (2020) Tussen verveling en vereenzaming: Een kwalitatief onderzoek naar hoe ouderen met een Marokkaanse achtergrond eenzaamheid en ouder worden in Nederland beleven [Between boredom and loneliness: A qualitative study of how older adults with a Moroccan background experience loneliness and ageing in the Netherlands]. Utrecht: Kennisplatform Integratie $\&$ Samenleving 
Norman A (1985) Triple jeopardy: growing old in a second homeland. Centre for Policy on Ageing, London

Palmberger M (2017) Social ties and embeddedness in old age: older Turkish labour migrants in Vienna. J Ethnic Migrat Stud 43:235249. https://doi.org/10.1080/1369183X.2016.1238907

Patzelt A (2017) 'A totally new world has been opening up for me'Experiences of older German migrants who are actively involved in the German-speaking community in Ottawa, Canada. J Ethnic Migrat Stud 43:218-234. https://doi.org/10.1080/1369183X.2016. 1238906

Peplau L, Perlman D (1982) Perspectives on loneliness. In: Peplau L, Perlman D (eds) Loneliness: a source book of current theory, research and therapy. John Wiley \& Sons, New York, pp 1-18

Prohaska T, Burholt V, Burns A et al (2020) (2020) Consensus statement: loneliness in older adults, the 21 st century social determinant of health? BMJ Open 10:e034967. https://doi.org/10.1136/ bmjopen-2019-034967

Salma J, Salami B (2020) "Growing old is not for the weak of heart": social isolation and loneliness in Muslim immigrant older adults in Canada. Health Soc Care Commun 25:e12226. https://doi.org/ 10.1111/hsc. 12894

Salway S, Such E, Preston L, Booth A, Zubair M, Victor C, Raghavan R (2020) Reducing loneliness among migrant and ethnic minority people: a participatory evidence synthesis. Public Health Res. https://doi.org/10.3310/phr08100

Sampaio D, King R, Walsh K (2018) Geographies of the ageing-migration nexus: an introduction. Area 50:440-443. https://doi.org/10. 1111/area. 12463

Schellingerhout R (2004) Gezondheid en welzijn van allochtone ouderen [Health and well-being of older migrants]. Sociaal en Cultureel Planbureau

Skrbiš Z (2008) Transnational families: theorising migration, emotions and belonging. J Intercult Stud 29:231-246. https://doi.org/10. 1080/07256860802169188

Smits F, Ruiter S, Van Tubergen F (2010) Religious practices among Islamic immigrants: Moroccan and Turkish men in Belgium. J Sci Study Relig 49:247-263. https://doi.org/10.1111/j.1468-5906. 2010.01507.x

Steinbach A (2018) Older migrants in Germany. Popul Ageing 11:285306. https://doi.org/10.1007/s12062-017-9183-5
Ten Kate RLF, Bilecen B, Steverink N (2020) A closer look at loneliness: why do first-generation migrants feel more lonely than their native Dutch counterparts? Gerontologist 60:291-301. https://doi. org/10.1093/geront/gnz192

Tummala-Narra P, Sathasivam-Rueckert N, Sundaram S (2013) Voices of older Asian Indian immigrants: mental health implications. Prof Psychol Res Pract 44:1-10. https://doi.org/10.1037/a0027809

Van Tilburg TG, Fokkema T (2020) Stronger feelings of loneliness among Moroccan and Turkish older adults in the Netherlands: in search for an explanation. Eur J Ageing. https://doi.org/10.1007/ s10433-020-00562-x

Uysal-Bozkir Ö, Fokkema T, MacNeil-Vroomen JL, Van Tilburg TG, De Rooij SE (2017) Translation and validation of the De Jong Gierveld loneliness scale among older migrants living in the Netherlands. J Gerontol Series B Psychol Sci Soc Sci 72:109-119. https://doi.org/10.1093/geronb/gbv044

Victor CR, Burholt V, Martin W (2012) Loneliness and ethnic minority elders in Great Britain: an exploratory study. J Cross-Cult Gerontol. https://doi.org/10.1007/s10823-012-9161-6

Warnes AM, Friedrich K, Kellaher L, Torres S (2004) The diversity and welfare of older migrants in Europe. Ageing Soc 24:307-326. https://doi.org/10.1017/S0144686X04002296

Wu Z, Penning MJ (2015) Immigration and loneliness in later life. Ageing Soc 35:64-95. https://doi.org/10.1017/S0144686X13000470

Yang K, Victor C (2011) Age and loneliness in 25 European nations. Ageing Soc 31:1368-1388. https://doi.org/10.1017/S0144686X1 000139X

Zhang G, Zhan H (2009) Beyond the Bible and the cross: a social and cultural analysis of Chinese elders' participation in Christian congregations in the United States. Sociol Spectr 29:295-317. https://doi.org/10.1080/02732170802584526

Zoutewelle-Terovan M, Liefbroer AC (2018) Swimming against the stream: non-normative family transitions and loneliness in later life across 12 nations. Gerontologist 58:1096-1108

Publisher's Note Springer Nature remains neutral with regard to jurisdictional claims in published maps and institutional affiliations. 